\title{
PENINGKATAN KEMANDIRIAN DAN HASIL BELAJAR IPS MENGGUNAKAN MODEL DISCOVERY LEARNING DI KELAS VIII SMP
}

\author{
Yenita Witri Anis
}

SMP Negeri Pua Kabupaten Agam

\begin{abstract}
Abstrak
Penelitian ini di dasari dari Pembelajaran IPS yang kurang menarik perhatian dan tidak melibatkan peserta didik menyebabkan mereka pasif dalam belajar sehingga tidak ada keinginan untuk mandiri dalam belajar.Tujuan penelitian ini untuk meningkatkan kemandirian peserta didik dalam belajar dan pda akhirnya meningkatkan hasil belajar peserta didik.Penelitian ini menggunkan metode penelitian tindakan kelas (PTK). Subjek penelitian ini adalah kelas VIII.1 yang berjumlah 25 orang terdiri dari 11 orang lakilaki dan 14 orang perempuan di SMPN 3 Sungai Pua Kab. Agam.Hasil penelitian menunjukkan peningkatan kemandirian peserta didik dalam belajar dan meningkatkan hasil belajar mereka.
\end{abstract}

Kata kunci: kemandirian belajar, hasil belajar, model discovery learning

c) (1) This is an open access article distributed under the Creative Commons Attribution License, which permits unrestricted use, distribution, and reproduction in any medium, provided the original work is properly cited. C2017 by author and IICET.

\section{PENDAHULUAN}

Globalisasi yang terjadi saat ini berdampak positif dan negative pada kehidupan.Khususnya untuk peserta didik dapat berdampak negatif jika tidak digunakan dengan baik.Fenomena tersebut terlihat dari beberapa kasus yang makin marak terjadi belakangan ini seperti penyalahgunaan obat dan alkohol, perkelahian antar pelajar, reaksi emosional yang berlebihan, kemalasan, tindakan konsumtif berlebihan serta berbagai perilaku yang mengarah pada tindakan kriminal. Oleh karena itu setiap peserta didik perlu membentengi dirinya dengan memiliki sikap kemandirian. Kemandirian akan ditunjukkan dalam tindakan sehari-hari seperti mengontrol diri, bertanggungjawab, rasa percaya diri dan inisiatif dalam bertindak, terutama ketika berlangsungnya proses pembelajaran di sekolah. Diharapkan para peserta didik memiliki kemandirian dalam belajar.

Belajar mandiri bukan berarti belajar sendiri.Seringkali orang menyalahartikan belajar mandiri sebagai belajar sendiri. Bab II Undang-Undang Nomor 20 Tahun 2003 tentang Sistem Pendidikan Nasional (Ikapi, 2003: 15) menyatakan bahwa pendidikan nasional berfungsi mengembangkan kemampuan dan membentuk watak serta peradaban bangsa yang bermartabat dalam rangka mencerdaskan kehidupan bangsa, bertujuan untuk berkembangnya potensi peserta didik agar menjadi manusia yang beriman dan bertaqwa kepada Tuhan Yang 
Maha Esa, berakhlak mulia, sehat, berilmu, cakap, kreatif, mandiri, dan menjadi warga negara yang demokratis, serta bertanggung jawab. Jelaslah bahwa kata mandiri telah muncul sebagai salah satu tujuan pendidikan nasional kita.Karena itu penanganannya memerlukan perhatian khusus semua guru, apalagi tidak ada mata pelajaran khusus tentang kemandirian.

Salah satu upaya yang dapat dilakukan dalam bidang pendidikan untuk mengembangkan kemandirian yaitu melalui peningkatan kemandirian belajar di sekolah.Kemandirian belajar adalah kondisi aktifitas belajar yang mandiri tidak tergantung pada orang lain, memiliki kemauan serta bertanggung jawab sendiri dalam menyelesaikan masalah belajarnya. Kemandirian belajar akan terwujud apabila peserta didik mampu mengontrol sendiri segala sesuatu yang dikerjakan, mengevaluasi dan selanjutnya merencanakan sesuatu yang lebih dalam pembelajaran yang dilalui dan peserta didik juga mau aktif dalam proses pembelajaran. Oleh karena itu, seorang guru harus mampu mengajak peserta didik untuk mengembangkan kemandirian belajar, diantaranya melalui penerapan model pembelajaran yang tepat.

Model pembelajaran yang tepat adalah yang mengikutsertakan peserta didik secara aktif dan kreatif dimana guru bertindak sebagai fasilitator, koordinator, mediator dan motivator dalam proses pembelajaran. Soekamto dalam Trianto (2007: 5) mengemukakan maksud dari model pembelajaran adalah: "Kerangka konseptual yang melukiskan prosedur yang sistematis dalam mengorganisasikan pengalaman belajar untuk mencapai tujuan belajar tertentu, dan berfungsi sebagai pedoman bagi para perancang pembelajaran dan para pengajar dalam merencanakan aktivitas belajar mengajar'.Pengupayaan model pembelajaran yang tepat diharapkan peserta didik tertarik mengikuti proses pembelajaran khusus pada pembelajaran IPS yang merupakan mata pelajaran wajib di Sekolah Menengah Pertama (SMP). Mata pelajaran IPS dirancang untuk mempersiapkan peserta didik dalam mengembangkan ilmu pengetahuan, kemampuan dalam menghadapi kondisi-kondisi sosial, serta mampu memecahkan masalah-masalah didalamnya. Dalam UU No. 20 tahun 2003 tentang Sistem Pendidikan Nasional, Pasal 37 dikatakan bahwa:

"IPS merupakan bahan kajian yang wajib dimuat dalam kurikulum pendidikan dasar dan menengah yang antara lain mencakup ilmu bumi/geografi, sejarah, ekonomi, kesehatan dan lain sebagainya yang dimaksud untuk mengembangkan pengetahuan, pemahaman, dan kemampuan analisis peserta didik terhadap kondisi sosial masyarakat".

Pembelajaran IPS diharapkan mampu membentuk kepribadian peserta didik yang lebih mandiri dan bijak, guna menanggulangi permasalahan sosial yang timbul.Pembelajaran IPS diharapkan dapat menjadikan peserta didik memiliki kemampuan untuk bertindak secara rasional dalam memecahkan masalah-masalah sosial yang dihadapinya dan memiliki kemampuan untuk mengambil keputusan sehingga nantinya peserta didik dapat mempertanggungjawabkan setiap keputusan yang diambilnya.Dengan demikian diharapkan dapat menciptakan sumber daya manusia yang memiliki tanggung jawab yang besar terhadap dirinya dan lingkungan sosialnya (Wijayanthi, 2014: 4).

Hasil observasi awal terhadap pembelajaran IPS kelas VIII.1 di SMP Negeri 3 Sungai Pua Kabupaten Agam, diketahui bahwa kurangnya keberanian peserta didik dalam menyampaikan pendapat. Saat guru mengajukan pertanyaan, peserta didik tidak dapat menjawab pertanyaan.Sehingga komunikasi dua arah yang dinamis tidak terjadi. Akibatnya proses belajar didominasi oleh guru dan terkesan membosankan. Bila diberikan penugasan maka peserta didik cenderung menyalin buku sumber yang mereka miliki, tanpa ada keinginan untuk menemukan sendiri jawaban atau secara kreatif mengambil contoh dari lingkungan disekitar mereka.Hal ini menunjukkan bahwa kemandirian peserta didik dalam belajar sangat kurang.

Pembelajaran IPS yang kurang menarik perhatian dan tidak melibatkan peserta didik menyebabkan mereka pasif dalam belajar sehingga tidak ada keinginan untuk mandiri dalam belajar. Lebih jauh lagi hal ini akan bermuara pada hasil belajar yang dicapai oleh peserta didik. Hasil belajar merupakan bagian terpenting dalam pembelajaran.Nana Sudjana (2009) mendefinisikan hasil belajar peserta didik pada hakikatnya adalah perubahan tingkah laku sebagai hasil belajar.Pengertian yang lebih luas mencakup bidang kognitif, afektif, dan psikomotorik. Bagi peserta didik yang memiliki kemandirian belajar pada umumnya akan mencapai kesuksesan atau keberhasilan dalam mengerjakan tugas-tugas yang sukar dan kompleks. Sebaliknya bagi peserta didik yang kemandirian masih kurang kemungkinan mengerjakan tugas-tugas yang menantang juga kurang 
berhasil.Demikian juga dengan peserta didik kelas VIII.1 SMP Negeri 3 Sungai Pua, terlihat hasil belajar mereka pada tabel dibawah ini:

Tabel 1. Nilai Rata-Rata Pembelajaran IPS Peserta Didik kelas VIII.1 SMP Negeri 3 Sungai Pua

\begin{tabular}{clcc}
\hline No. & \multicolumn{1}{c}{ Ujian } & Nilai Rata-Rata & KKM \\
\hline $\mathbf{1}$ & Mid Semester 1 & 72,70 & 75 \\
$\mathbf{2}$ & Semester 1 & 70,64 & 75 \\
\hline
\end{tabular}

Tabel 1 didasarkan pada Kriteria Ketuntasan Minimum (KKM) pada pembelajaran IPS. Tabel tersebut menunjukkan bahwa kemandirian belajar peserta didik kelas VIII.1 sangat kurang dan tercermin pada nilai ratarata yang diperoleh sangat jauh dari capaian KKM yang ditargetkan yaitu 75 .

Kegagalan pendidik dalam melaksanakan pembelajaran tak selalu disebabkan oleh kurang mendalamnya pemahaman pendidik terhadap bahan ajar, akan tetapi dapat pula disebabkan oleh kurang tepatnya metode dan strategi yang digunakan pendidik dalam proses pembelajaran. Penggunaaan metode dan strategi pembelajaran yang kurang tepat serta pembelajaran yang masih berpusat pada guru (teacher centered) memicu rendahnya pemahaman peserta didik terhadap materi ajar yang dipelajari sehingga pembelajaran bermakna yang diinginkan sulit tercapai. Jika hal ini dibiarkan tidak hanya berdampak buruk terhadap kemampuan dan pengetahuan peserta didik, tetapi juga akan berdampak terhadap mutu pendidikan di Sekolah Menengah Pertama Negeri 3 Sungai Pua.

Berdasarkan kondisi di atas, maka guru sebagai tenaga pendidik harus melakukan suatu inovasi dalam pembelajaran IPS. Guru perlu mengembangkan pembelajaran yang dapat meningkatkan aktivitas dan hasil belajar peserta didik. Untuk itu perlu adanya perubahan pembelajaran yang dilakukan oleh guru, seperti penggunaan metode atau model pembelajaran yang bervariasi.Pada pembelajaran IPS salah satu model yang dianggap tepat digunakan yaitu model pembelajaran Discovery Learning yang dikemukakan oleh Jerome Bruner. Menurut Jerome Bruner dalam Wahab (2007: 93), penerapan model penemuan dalam pembelajaran IPS memberikan dorongan yang kuat terhadap peserta didik karena secara pribadi peserta didik terlibat (baik fisik maupun mental) dalam kegiatan pembelajaran. Pembelajaran dengan menggunakan model tersebut meminta/mensyaratkan peserta didik untuk menggunakan kemampuan nalarnya secara induktif.Kemampuan yang dimaksud ialah kemampuan yang digunakan untuk bernalar terhadap hal-hal yang bersifat khusus dari pengalaman pribadi sampai ke generalisasi.Dengan menggunakan metode ini guru memberikan kesempatan atau mendorong peserta didik untuk menemukan sendiri informasi.

Pembelajaran Discovery Learning, peserta didik didorong untuk belajar sendiri secara mandiri. Model ini menempatkan peserta didik sebagai pembelajar aktif dalam membangun pengetahuan yang diharapkan sehingga dapat meningkatkan kemadirian belajar untuk memperoleh pengalaman dan melakukan eksperimen-eksperimen yang mengizinkan mereka untuk menemukan prinsip-prinsip itu sendiri.Model Discovery Learning mengacu kepada teori belajar yang didefinisikan sebagai proses pembelajaran yang terjadi bila pelajar tidak disajikan dengan pelajaran dalam bentuk finalnya, tetapi diharapkan peserta didik mengorganisasi sendiri. Model discovery learningadalah model pembelajaran yang mengatur kegiatan yang dilakukan peserta didik sehingga mereka memperoleh pengetahuan dengan menemukan sendiri.

Guru dalam menerapkan model pembelajaran Discovery Learning berperan sebagai pembimbing dengan memberikan kesempatan kepada peserta didik untuk belajar secara aktif, membimbing, dan mengarahkan kegiatan belajar peserta didik sesuai dengan tujuan. Kondisi seperti ini merubah kegiatan pembelajaran yang biasanya teacher oriented menjadi student oriented. Dalam pembelajaran Discovery Learning, guru harus memberikan kesempatan bagi peserta didik untuk menjadi seorang problem solver, seorang scientis, historin, atau ahli IPS.Bahan ajar tidak disajikan dalam bentuk akhir, tetapi peserta didik dituntut untuk melakukan berbagai kegiatan menghimpun informasi, membandingkan, mengkategorikan, menganalisis, mengintegrasikan, mengorganisasikan bahan serta membuat kesimpulan-kesimpulan.Berdasarkan latar belakang masalah di atas, maka identifikasi masalahnya yaitu bagaimanakah meningkatkan kemandirian dan hasil belajar IPS menggunakan Model Discovery Learning di Kelas VIII SMP. 


\section{METODE}

Penelitian ini menggunakan metode Penelitian Tindakan Kelas (Classroom Action Research). Menurut Haryono (2015) Penelitian Tindakan Kelas (PTK) adalah suatu bentuk penelitian yang bersifat reflektif dengan melakukan tindakan-tindakan tertentu agar dapat memperbaiki dan atau meningkatkan praktek-praktek pembelajaran di kelas secara lebih profesional.Penelitian ini dilaksanakan dengan mengikuti model yang dikembangkan oleh Kemmis dan Mc. Taggart, sebagai suatu bentuk self enquiry kolektif yang dilakukan oleh para partisipan didalam situasisosial untuk meningkatkan rasionalitas dan keadilan dari praktik sosial atau pendidikan yang mereka lakukan, serta mempertinggi pemahaman mereka terhadap praktik dan situasi tempat praktik itu dilaksanakan. PTK dilaksanakan dalam proses berdaur yang terdiri dari empat tahapan yaitu plan, action, observation, and reflection (Waitlem, 2015).Pelaksanaan tindakan dibagi atas 2 siklus, dimana masingmasing siklus terdiri dari 3 kali pertemuan.Selama melaksanakan penelitian, peneliti berkolaborasi dengan guru mata pelajaran IPS di sekolah yang membantu dalam melaksanakan penelitian sekaligus bertindak sebagai observer.

Penelitian tindakan kelas ini dilakukan di SMP Negeri 3 Sungai Pua Kabupaten Agam. Subjek penelitian ini adalah peserta didik kelas VIII.1 yang berjumlah 25 orang terdiri dari 11 orang laki-laki dan 14 orang perempuan.Penelitian tindakan kelas ini berhenti apabila proses pembelajaran telah menampakkan kemandirian belajar yang tinggi, dalam hal ini mencapai $80 \%$ dan hasil belajar menunjukkan sekurang-kurangnya $80 \%$ dari seluruh peserta didik telah mencapai nilai ketuntasan minimal yaitu 75. Peserta didik telah memiliki kemandirian belajar apabila kondisi aktivitas belajar tidak tergantung pada orang lain, memiliki kemauan serta bertanggung jawab sendiri dalam menyelesaikan masalah belajarnya. Kemandirian belajar akan terwujud apabila peserta didik aktif mengontrol sendiri segala sesuatu yang dikerjakan, mengevaluasi dan selanjutnya merencanakan sesuatu yang lebih dalam proses pembelajaran yang dilalui dan peserta didik juga mau aktif dalam proses pembelajaran. Setelah proses pembelajaran berakhir guru melakukan evaluasi untuk memperoleh hasil belajar.

Sumber data penelitian ini diperoleh dari pengamatan langsung selama proses pembelajaran. Pengamatan dilakukan berkaitan dengan aktivitas peserta didik dan aktivitas guru di kelas. Pengamatan aktivitas pembelajaran yang dilakukan peserta didik berkaitan dengan kemandirian belajar dan aktivitas guru menggunakan model discovery learning. Selain itu peneliti juga memberikan angket kepada peserta didik untuk mengetahui pendapat mereka dalam menggunakan model pembelajaran discovery learning.Pengamatan kemandirian belajar peserta didik dalam proses memuat beberapa indikator kemandirian belajar yaitu: 1) percaya diri, 2) displin, 3) inisiatif, 4) tanggung jawab, 5) motivasi.

Menurut kamus besar Bahasa Indonesia (2005:85) menyebutkan bahwa "Percaya kepada diri sendiri berarti yakin benar atau memastikan akan kemampuan atau kelebihan seseorang atau sesuatu (bahwa akan dapat memenuhi harapan-harapannya)". Percaya diri peserta didik pada proses pembelajaran mata pelajaran IPS dapat diamati berdasarkan lima kriteria yaitu mengikuti kegiatan presentasi di depan kelas, ketenangan dalam berbicara, keikutsertaan dalam mengajukan pertanyaan, keikutsertaan dalam menjawab pertanyaan dan keikutsertaan dalam berpendapat.Disiplin merupakan sesuatu yang berkenaan dengan pengendalian diri atau kepatuhan seseorang untuk mengikuti bentuk-bentuk aturan atas kesadaran pribadinya, disiplin dalam belajar merupakan kemauan untuk belajar yang didorong oleh diri peserta didik sendiri. Dalam penelitian ini, disiplin peserta didik dapat diamati dari tingkah laku yang muncul selama proses pembelajaran berlangsung yaitu bertanggung jawab terhadap tugas yang diberikan, semangat dan antusias dalam kegiatan pembelajaran, komitmen yang tinggi terhadap tugas, mengatasi kesulitan yang timbul pada dirinya, mematuhi peraturan yang ditetapkan.

Menurut kamus besar Bahasa Indonesia (2005:395) "Inisiatif adalah kemampuan untuk mencipta atau daya cipta”. Inisiatif dalam penelitian ini dapat dilihat dalam proses kegiatan pembelajaran. Inisiatif peserta didik yang diamati adalah memiliki dorongan rasa ingin tahu yang tinggi, keterampilan berfikir luwes, keterampilan berfikir lancar, keterampilan berfikir orisinil, berani mengambil resiko.Tingkat tanggung jawab peserta didik dapat diamati melalui aktifitas selama proses pembelajaran mata pelajaran IPS dengan beberapa aspek. Aspek yang berkaitan dengan tanggung jawab adalah keikutsertaan peserta didik dalam melaksanakan tugas yang diberikan kepadakelompok, keikutsertaan dalam memecahkan masalah, kepedulian terhadap kesulitan sesama anggota kelompok, keikutsertaan dalam membuat laporan kelompok, keikutsertaan dalam melaksanakan presentasi hasil diskusi. 
Motivasi dalam penelitian ini diamati selama proses pembelajaran berlangsung. Indikator yang digunakan untuk mengamati motivasi adalah ingin menyelesaikan tugas dengan cepat, menyukai dan melihat tantangan secara seimbang, berani menghadapi resiko, memiliki tanggung jawab personal yang tinggi, kemampuan memimpin.

\section{HASIL DAN PEMBAHASAN}

\section{Hasil Penelitian}

\section{Siklus I}

\section{Perencanaan}

Persiapan yang dilakukan pada perencanaan siklus I adalah sebagai berikut:

1. Mempersiapkan silabus.

2. Membuat Rencana Pelaksanaan Pembelajaran (RPP) siklus I yang bercirikan pembelajaran menggunakan model Discovery Learning.

3. Mempersiapkan bahan ajar.

4. Mempersiapkan media pembelajaran.

5. Mempersiapkan soal ulangan harian dan kunci jawaban.

6. Mempersiapkan angket.

7. Mempersiapkan catatan lapangan siklus I.

\section{Pelaksanaan}

Kegiatan yang dilakukan dalam penerapan model Discovery Learning adalah melaksanakan 6 langkah pembelajaran yaitu: 1) Stimulastion (pemberian ransangan), 2) Problem Statement (pernyataan/identifikasi masalah), 3) Data Collection (pengumpulan data), 4) Data Rocessing (pengolahan data), 5) Verification (pembuktian/pemahaman), 6) Generalization (menarik kesimpulan). Pelaksanaan pembelajaran disesuaikan dengan tindakan skenario pembelajaran yang telah dibuat oleh guru dan diamati oleh kolaborator untuk setiap pertemuan pembelajaran. Tindakan pembelajaran yang dilakukan mengikuti tahapan sebagai berikut:

\section{Pertemuan Pertama}

1. Stimulasi (pemberian rangsangan)

Guru menampilkan beberapa gambar pada Perang Dunia II. Guru mengajukan pertanyaan untuk melihat pengetahuan awal peserta didik sebagai prasyarat sebelum memasuki tahap pembelajaran tentang latar belakang Jepang ikut terlibat dalam perang dunia II.Guru memperkenalkan cara belajar dengan model Discovery Learning, memotivasi peserta didik agar terlibat aktif dalam pembelajaran.

2. Pengumpulan Data

Peserta didik dibagi menjadi 4 kelompok.Kelompok 1 dan 3 mengumpulkan data tentang tindakan-tindakan Jepang untuk memenuhi ambisinya menguasai Asia Timur Raya.Kelompok 2 dan 4 membahas langkahlangkah Jepang setelah terdesak pada Perang Dunia II.Peserta didik membaca buku sumber dan mengumpulkan informasi untuk menjawab pertanyaan yang terdapat pada lembar kerja kelompok.

3. Pengolahan Data

Peserta didik melakukan diskusi di kelompoknya untuk menjelaskan setiap pertanyaan pada lembar kerja peserta didik. Guru membantu kelompok yang menemui kendala.

4. Verifikasi (pembuktian)

Masing-masing kelompok peserta didik menjelaskan hasil temuannya secara bergantian dan kelompok lain menanggapi hasil diskusi kelompok yang tampil.

5. Menarik Kesimpulan

Guru mengarahkan peserta didik untuk dapat menarik rangkuman pembelajaran.

\section{Pertemuan Kedua}

1. Stimulasi (pemberian rangsangan)

Guru mengajukan pertanyaan untuk melihat pengetahuan awal peserta didik sebagai prasyarat sebelum memasuki tahap pembelajaran tentang Pembentukan BPUPKI.Guru menjelaskan tentang kemajuan proses 
pembelajaran dengan menggunakan Model Discovery Learning dan hal-hal yang perlu diperbaiki peserta didik untuk peningkatan kemandirian belajar mereka (motivasi).Guru menampilkan gambar dr. Radjiman Wedyodiningrat dan Ir. Soekarno. Guru mengadakan sedikit tanya jawab tentang kronologi Perang Dunia II di Asia Pasifik.

2. Pengumpulan Data

Guru membagi peserta didik atas 4 kelompok, setiap kelompok diberikan lembaran kerja kelompok. Kelompok 1 dan 3 membahas tentang alasan Jepang membentuk BPUPKI dan Sidang I BPUPKI. Kelompok 2 dan 4 membahas tentang proses pembentukan dasar negara Indonesia merdeka. Peserta didik membaca buku sumber dan mengumpulkan informasi untuk menjawab pertanyaan yang terdapat pada lembar kerja kelompok.

3. Pengolahan Data

Peserta didik melakukan diskusi di kelompoknya untuk menjelaskan setiap pertanyaan pada lembar kerja peserta didik.

4. Verifikasi (pembuktian)

Masing-masing kelompok peserta didik menjelaskan hasil temuannya secara bergantian dan kelompok lain menanggapi hasil diskusi kelompok yang tampil.

5. Menarik Kesimpulan

Guru mengadakan tanya jawab dengan peserta didik hingga peserta didik dapat menarik simpulan materi.

\section{Pertemuan Ketiga}

1. Stimulasi (pemberian rangsangan)

Guru mengajukan pertanyaan untuk melihat pengetahuan awal peserta didik sebagai prasyarat sebelum memasuki tahap pembelajaran tentang Proses Persiapan Kemerdekaan Indonesia.Guru menampilkan gambar suasana Sidang BPUPKI, dan mengadakan sedikit tanya jawab.

2. Pengumpulan Data

Guru membagi peserta didik atas 4 kelompok, setiap kelompok diberikan lembaran kerja kelompok. Kelompok 1 dan 3 membahas tentang proses pembentukan dasar dan konstitusi negara Indonesia merdeka (Sidang BPUPKI II). Kelompok 2 dan 4 membahas tentang pembentukan dan peranan PPKI dalam kemerdekaan Indonesia.

3. Pengolahan Data

Masing-masing kelompok mengerjakan tugas dan menyimpulkan hasil diskusi mereka.

4. Verifikasi Data

Masing-masing kelompok peserta didik menjelaskan hasil temuannya secara bergantian dan kelompok lain menanggapi hasil diskusi kelompok yang tampil.

5. Menarik Kesimpulan

Peserta didik menyimpulkan seluruh materi dari tiap-tiap kelompok, dibantu oleh guru.Kelompok terbaik mendapatkan penghargaan dari guru.

\section{Siklus II}

\section{Pertemuan Pertama}

1. Stimulasi (pemberian rangsangan)

Guru menampilkan gambar peta Rengasdengklok. Kemudian mengajukan beberapa pertanyaan tentang hubungan daerah Rengasdengklok dengan peristiwa proklamasi kemerdekaan Indonesia.

2. Pengumpulan Data

Guru membagi peserta didik atas 4 kelompok, setiap kelompok diberikan lembaran kerja kelompok. Kelompok 1 dan 3 membahas tentang latar belakang terjadinya peristiwa Rengasdengklok beserta kronologi dan tokohtokoh yang terlibat di dalamnya.Kelompok 2 dan 4 membahas tentang perumusan naskah proklamasi dan ppelaksanaan proklamasi kemerdekaan Indonesia.

3. Pengolahan Data

Masing-masing kelompok mengerjakan tugas dan menyimpulkan hasil diskusi mereka.

\section{Verifikasi Data}


Masing-masing kelompok peserta didik menjelaskan hasil temuannya secara bergantian dan kelompok lain menanggapi hasil diskusi kelompok yang tampil.

5. Menarik Kesimpulan

Guru menantang masing-masing peserta didik untuk dapat menulis 4 butir kesimpulan, kemudian ditampilkan ke depan kelas. Terakhir, mengambil kesimpulan bersama.

\section{Pertemuan Kedua}

1. Stimulasi (pemberian rangsangan)

Guru mengajak peserta didik menyanyikan lagu kebangsaan Indonesia Raya. Kemudian memberikan pertanyaan seputar penggerek bendera dan pencipta lagu tersebut. Guru meminta peserta didik membaca materi mengenai makna dan arti penting proklamasi kemerdekaan Indonesia.

2. Pengumpulan Data

Peserta didik duduk menurut kelompoknya masing-masing.Kelompok 1 dan 3 membahas Penyebaran berita proklamasi dan sidang PPKI I dan II.Kelompok 2 dan 4 membahas Dukungan daerah terhadap pembentukan negara kesatuan dan pemerintahan RI.

3. Pengolahan Data

Masing-masing kelompok dipersilakan mengolah data yang didapat untuk dapat ditampilkan.

4. Verifikasi data

Masing-masing kelompok menampilkan hasil diskusi kelompoknya.Setiap peserta didik diharuskan mempersiapkan sebuah pertanyaaan untuk diajukan pada kelompok penampil dengan sistem lot.

5. Menarik Kesimpulan

Kelompok ganjil bergabung untuk meramu kesimpulan materinya, begitu pula dengan kelompok genap.

\section{Pertemuan Ketiga}

1. Stimulasi (pemberian rangsangan)

Guru menampilkan potongan-potongan gambar yang berhubungan dengan peristiwa proklamasi. Kemudian diajukan pertanyaan kepada peserta didik tentang gambar tersebut.

2. Pengumpulan Data

Guru membagi peserta didik atas 4 kelompok, setiap kelompok diberikan satu lembar karton manila, sebotol lem dan sepaket potongan gambar. Peserta didik ditugaskan menyusun seluruh kronologi gambar tersebut, mulai dari kekalahan Jepang sampai dukungan daerah terhadap terbentuknya Republik Indonesia.Peserta didik diminta mencari bahan yang berhubungan dengan gambar tersebut.

3. Pengolahan Data

Masing-masing kelompok mengerjakan tugas dan menyimpulkan hasil diskusi mereka.

4. Verifikasi Data

Masing-masing kelompok peserta didik menjelaskan hasil temuannya secara bergantian dan kelompok lain menanggapi hasil diskusi kelompok yang tampil.

5. Menarik Kesimpulan

Guru membantu peserta didik menilai kelompok mana yang paling banyak betul dalam menyusun kronologi tersebut. Kemudian peserta didik menyimpulkan materi.

\section{Pelaksanaan}

\section{Siklus I}

Berdasarkan hasil pengamatan kolaborator terhadap aktivitas belajar peserta didik dengan menggunakan Model Discovery diperoleh data kemandirian belajar peserta didik pada pertemuan pertama siklus I pada tabel berikut ini.

Tabel 2. Kemandirian Belajar Peserta Didik Pada Siklus I

\begin{tabular}{lllcccccc}
\hline No. & & Aspek yang diamati & \multicolumn{3}{c}{ Pertemuan } & Rata-rata & Kategori \\
\cline { 3 - 7 } & & & I & II & III & & \\
$\mathbf{1}$ & Percaya Diri & & 60 & 70 & 75 & 68.33 & Baik \\
$\mathbf{2}$ & Disiplin & 70 & 70 & 75 & 71.66 & Baik \\
\hline
\end{tabular}




\begin{tabular}{|c|c|c|c|c|c|c|}
\hline 3 & Inisiatif & 75 & 65 & 75 & 71.66 & Baik \\
\hline 4 & Tanggung Jawab & 75 & 75 & 75 & 75 & Baik \\
\hline 5 & Motivasi & 70 & 70 & 70 & 70 & Baik \\
\hline
\end{tabular}

Pada tabel 2 dapat dilihat bahwa kemandirian peserta didik secara keseluruhan sudah baik.Dilihat dari aspek yang diamati terlihat aspek percaya diri dan disiplin mengalami peningkatan.Sedangkan aspek tanggungjawab dan motivasi terlihat tetap.Sedangkan aspek inisiatif cenderung turun pada pertemuan kedua, tetapi meningkat kembali pada pertemuan ke-3.

\section{Hasil Belajar}

Ketuntasan hasil belajar peserta didik dalam menganalisis materi Persiapan Kemerdekaan Indonesia dengan menggunakan Model Discovery Learning dapat dilihat pada tabel berikut adalah:

\section{Tabel 3. Hasil Belajar Peserta Didik Pada Siklus I}

\begin{tabular}{cccc}
\hline No. & Jumlah Peserta didik & $\mathbf{( \% )}$ & Kategori ketuntasan \\
\hline $\mathbf{1}$ & 19 orang & $76 \%$ & Tuntas \\
$\mathbf{2}$ & 6 orang & $24 \%$ & Tidak Tuntas \\
\hline
\end{tabular}

Berdasarkan tabel ketuntasan hasil belajar peserta didik secara individu dalam menganalisis Persiapan Kemerdekaan Indonesia pada siklus I dari 25 orang peserta didik, 19 orang diantaranya telah mencapai ketuntasan $(\mathrm{KKM}=75)$ sedangkan peserta didik yang belum tuntas adalah 6 orang. Sedangkan secara klasikal kelas VIII. 1 mencapai ketuntasan $76 \%$ dengan nilai rata-rata 75 , dan yang belum tuntas $24 \%$.

\section{Siklus II}

Hasil pengamatan kolaborator terhadap aktivitas belajar peserta didik dengan menggunakan Model Discovery maka diperoleh data penilaian kemandirian belajar peserta didik pada pertemuan pertama siklus II pada tabel berikut ini.

Tabel 4. Kemandirian Belajar Peserta Didik Pada Siklus II

\begin{tabular}{llcccccc}
\hline & Aspek yang diamati & \multicolumn{3}{c}{ Pertemuan } & Rata-rata & \multicolumn{2}{c}{ Kategori } \\
\cline { 3 - 6 } & & I & II & III & & & \\
$\mathbf{1}$ & Percaya Diri & 75 & 75 & 80 & 76.66 & Baik \\
$\mathbf{2}$ & Disiplin & 80 & 80 & 85 & 81.66 & Sangat Baik \\
$\mathbf{3}$ & Inisiatif & 80 & 85 & 85 & 83.33 & Sangat Baik \\
$\mathbf{4}$ & Tanggung Jawab & 75 & 75 & 75 & 75 & Baik \\
$\mathbf{5}$ & Motivasi & 75 & 75 & 80 & 76.66 & Baik \\
\hline
\end{tabular}

Pada tabel 4 dapat dilihat bahwa kemandirian peserta didik secara keseluruhan sudah ada baik da nada yang sangat baik.Dilihat dari aspek yang diamati semuanya terlihat meningkat kecuali tanggungjawab.Sedangkan disiplin dan inisiatif sudah berada pada kategori sangat baik.

\section{Hasil Belajar}

Ketuntasan hasil belajar peserta didik dalam menganalisis materi Persiapan Kemerdekaan Indonesia dengan menggunakan Model Discovery Learning dapat dilihat pada tabel berikut adalah:

Tabel 5. Hasil Belajar Siklus II

\begin{tabular}{cccc}
\hline No. & Jumlah Peserta didik & $\mathbf{( \% )}$ & Kategori ketuntasan \\
\hline $\mathbf{1}$ & 21 orang & $84 \%$ & Tuntas \\
$\mathbf{2}$ & 4 orang & $16 \%$ & Tidak Tuntas \\
\hline
\end{tabular}


Berdasarkan tabel ketuntasan hasil belajar peserta didik secara individu dalam menganalisis Persiapan Kemerdekaan Indonesia pada siklus II dari 25 orang peserta didik, 21 diantaranya telah mencapai ketuntasan $(\mathrm{KKM}=75)$ sedangkan peserta didik yang belum tuntas hanya 4 orang. Sedangkan secara klasikal kelas VIII.1 mencapai ketuntasan $84 \%$ dengan nilai rata-rata 75 , dan yang belum tuntas $16 \%$.

\section{Pembahasan}

Kemandirian belajar adalah belajar mandiri, tidak menggantungkan diri kepada orang lain, peserta didik dituntut untuk memiliki keaktifan dan inisiatif sendiri dalam belajar, bersikap, berbangsa maupun bernegara (Abu Ahmadi dan Nur Uhbiyati, 1990). Menurut Stephen Brookfield (2000) kemandirian belajar merupakan kesadaran diri, digerakkan oleh diri sendiri, kemampuan belajar untuk mencapai tujuannya.Susilawati, (2009) mendeskripsikan kemandirian belajar sebagai berikut: 1) Peserta didik berusaha untuk meningkatkan tanggung jawab dalam mengambil berbagai keputusan. 2) Kemandirian dipandang sebagai suatu sifat yang sudah ada pada setiap orang dan situasi pembelajaran. 3) Kemandirian bukan berarti memisahkan diri dari orang lain. 4) Pembelajaran mandiri dapat mentransfer hasil belajarnya yang berupa pengetahuan dan keterampilan dalam berbagai situasi. 5) Peserta didik yang belajar mandiri dapat melibatkan berbagai sumber daya dan aktivitas seperti membaca sendiri, belajar kelompok, latihan dan kegiatan korespondensi.Berdasarkan pendapat susilawati yang no 2, maka kemandirian itu dapat dilatihkan kepada peserta didik. Hasil latihan yang dilakukan guru untuk melatih siswa lebih mandiri dengan menggunakan metode discovery learning sangat berhasil. Hal ini terlihat adanya peningkatan kemandirian disetiap pertemuan.

Anak yang mempunyai kemandirian belajar dapat dilihat dari kegiatan belajarnya, dia tidak perlu disuruh bila belajar dan kegiatan belajar dilaksanakan atas inisiatif dirinya sendiri.Untuk mengetahui apakah peserta didik itu mempunyai kemandirian belajar maka perlu diketahui ciri-ciri kemandirian belajar. Menurut Sardiman sebagaimana dikutip oleh Ida Farida Achmad (2008) menyebutkan bahwa ciri-ciri kemandirian belajar yaitu meliputi:

a. Adanya kecenderungan untuk berpendapat, berperilaku dan bertindak atas kehendaknya sendiri.

b. Memiliki keinginan yang kuat untuk mencapai tujuan.

c. Membuat perencanaan dan berusaha dengan ulet dan tekun untuk mewujudkan harapan.

d. Mampu untuk berfikir dan bertindak secara kreatif, penuh inisiatif dan tidak sekedar meniru.

e. Memiliki kecenderungan untuk mencapai kemajuan, yaitu untuk meningkatkan prestasi belajar.

f. Mampu menemukan sendiri tentang sesuatu yang harus dilakukan tanpa mengharapkan bimbingan dan tanpa pengarahan orang lain.

Menurut Gibbons (2002), ada beberapa karakteristik yang dihubungkan dengan kemandirian belajar pada peserta didik yaitu:

a. Independence

Peserta didik yang belajar secara mandiri bertanggung jawab secara mandiri terhadap analisa, rencana, pelaksanaan dan mengevaluasi sendiri aktivitas pembelajarannya.

\section{b. Self Management}

Peserta didik yang belajar secara mandiri dapat mengidentifikasikan apa yang mereka butuhkan selama proses pembelajaran, mengatur tujuan belajar, mengontrol waktu mereka sendiri dan berusaha untuk belajar dan membuat ataupun mengatur feedback dari pekerjaan mereka.

c. Desire for learning

Untuk dapat mencapai tujuan pembelajaran dan mendapatkan pengetahuan, peserta didik yang belajar secara mandiri harus memiliki motivasi yang kuat.

d. Problem-solving

Untuk mencapai hasil belajar yang terbaik, pelajar menggunakan sumber pembelajaran dari lingkungan eksternal dan menggunakan strategi belajar yang memungkinkan yang terjadi selama proses pembelajaran.

Peserta didik dikatakan mandiri apabila: 1) Berani bertanya dan mengemukakan pendapat, 2) Semangat dan antusias dalam mengikuti pembelajaran, 3) Memiliki motivasi yang tinggi dalam belajar, 4) Bertanggungjawab terhadap apa yang telah dilakukan dalam belajar dan 5) Disiplin dalam mengikuti proses belajar mengajar.

Hasil belajar merupakan dampak terhadap kemandirian peserta didik. Jika peserta didik sudah mandiri, maka mereka akan menyadari bahwa mereka memiliki tanggungjawab yang besar terhadap pembelajaran yang 
dilaksanakannya. Hal ini terbukti bahwa hasil belajar peserta didik dari siklus I ke siklus II meningkat.Begitu juga ketuntasan dalam belajar.Peserta didik sudah mencapai $84 \%$ yang tuntas dalam mempelajari materi yang di kelola guru.Hasil belajar peserta didik dalam mata pelajaran IPS tidak hanya kognitif, termasuk hasil belajar afektif dan psikomotor. Hal ini sesuai dengan pendapat Sudjana (2004) mengatakan bahwa dalam sistem pendidikan nasional terdapat rumusan tujuan pendidikan, baik tujuan kurikuler maupun tujuan instruksional, pada umumnya menggunakan klasifikasi hasil belajar yang secara garis besar terbagi atas tiga ranah yaitu ranah kognitif, afektif dan psikomotoris dengan penjelasan sebagai berikut:

1) Ranah kognitif berkenaan dengan hasil belajar intelektual yang terdiri dari enam aspek, yakni: (a) knowledge (pengetahuan); (b) comprehension (pemahaman), kedua aspek ini disebut kognitif tingkat rendah; (c) aplikasi; (d) analisis; (e) sintesis dan (f) evaluasi, dimana keempat aspek ini termasuk kognitif tingkat tinggi.

2) Ranah afektif berkenaan dengan sikap yang terdiri dari lima aspek, yakni: (a) penerimaan; (b) jawaban atau reaksi; (c) penilaian; (d) organisasi; dan (e) internalisasi.

Ranah psikomotoris berkenaan dengan hasil belajar keterampilan dan kemampuan bertindak yang terdiri dari enam aspek yaitu: (a) gerakan refleks; (b) keterampilan gerakan dasar; (c) kemampuan perseptual; (d) keharmonisan atau ketepatan; (e) gerakan keterampilan kompleks; dan (f) gerakan ekspresif dan interpretative.

\section{SIMPULAN DAN SARAN}

Proses pembelajaran yang terencana pada setiap tahapan pembelajaran dengan menggunakan model Dicovery Learningdapat meningkatkan kemandirian peserta didik yaitu Kepercayaan diri, kedisiplinan dan inisiatif, Rasa tanggung jawab dan motivasi. Hasil belajar peserta didik dalam proses pembelajaran dengan menggunakan model Discovery Learning terjadi peningkatan dari siklus I ke siklus II.

Berdasarkan kesimpulan yang dapat disarankan terkait dengan model pembelajaran discovery learning dapat menggunakan model pembelajaran model discovery learning Saat kegiatan pengolahan dan verifikasi data sebaiknya guru lebih memperhatikan kegiatan peserta didik, selain daripada itu Guru lain agar dapat mengembangkan penelitian ini dengan materi yang berbeda.

\section{DAFTAR RUJUKAN}

Ikapi. (2003).Undang-undang Nomor 20 Tahun 2003 tentang Sistem Pendidikan Nasional.

Amelia, Nani. (2015). Penggunaan Model Discovery Learning untuk Meningkatkan Kemandirian dan Hasil Belajar Geografi Peserta Didik Kelas X.1 di SMA Negeri 5 Bukittinggi. Padang: UNP

Wahab Abdul Aziz. (2007). Metode dan Model-model Mengajar. Bandung: Alvabeta

Trianto. (2007). Model-model Pembelajaran Inovatif. Jakarta: Prestasi Pustaka Publisher.

Wijayanthi, A. A. Sagung Oka Vera. (2014). Pengaruh Model Pembelajaran Inkuiri Terbimbing Berbasis Kearifan Lokal Terhadap Tanggung Jawab Belajar Dan Hasil Belajar IPS Peserta didik Kelas V Sd Gugus I Gusti Ngurah Rai Denpasar Selatan. E-Journal Program Pascasarjana Universitas Pendidikan Ganesha Program Studi Pendidikan Dasar Vol. 4.

Budiada, I Wayan. (2012). Pengaruh Penerapan Model Pembelajaran Inkuiri Terbimbing Berbasis Asesmen Portofolio Terhadap Hasil Belajar Kimia Peserta didik Kelas X Ditinjau dari Adversity Quotient.Jurnal Penelitian dan Evaluasi Pendidikan Universitas Pendidikan Ganesha Vol. 2 No. 1 